\title{
A man with blue-grey nails
}

\section{Christopher Dalby}

\section{CASE}

A man aged 62 years who worked as school cleaner presented with concerns of a blue-grey colouration to all his nails. He had first noticed this change several weeks ago. His fingers and toes were not painful and he could not recall any cause or trauma for the change. He did not have bruising or bleeding elsewhere.

On examination, there was an identifiable blue-grey tinge of varying degrees on the proximal aspect of all his fingernails and toenails (Figures 1 and 2). There were no other skin changes found. The remainder of his examination was unremarkable. The patient's recent routine blood tests showed no abnormalities.

His current medical conditions and medications are summarised in Table 1.

\section{QUESTION 1}

What is the likely diagnosis?

\section{QUESTION 2}

What other conditions could be considered?

\section{ANSWER 1}

The likely diagnosis is medication-induced nail colouration secondary to prolonged minocycline use.

\section{ANSWER 2}

The differential diagnosis includes:

- medication-induced hyperpigmentation from another agent

- nail infection (eg onychomycosis or Pseudomonas spp. $)^{1}$

- heavy metal exposure (eg colloidal silver) ${ }^{2}$

- idiopathic discoloration.

\section{CASE CONTINUED}

A specialist dermatology review was organised. This confirmed the diagnosis of hyperpigmentation secondary to minocycline.

\section{QUESTION 3}

How common is minocycline-induced hyperpigmentation?

\section{QUESTION 4}

Which body areas can be affected by minocycline-induced pigmentation?

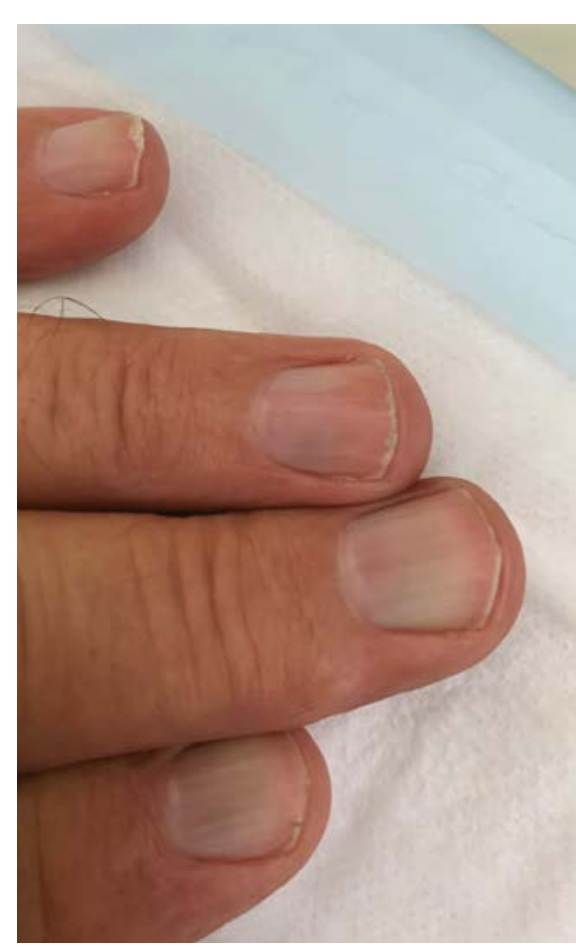

Figure 1. The patient's fingernails

\section{QUESTION 5}

What are the different types of minocyclineinduced hyperpigmentation and the corresponding histopathological findings?

\section{QUESTION 6}

What is the effect of dose and duration on the risk of developing hyperpigmentation?

\section{QUESTION 7}

What other medications are associated with nail and/or skin colouration change?

\section{QUESTION 8}

How should this condition be treated? Is the colouration likely to be permanent?

\section{ANSWER 3}

All tetracyclines (with the possible exception of doxycycline) have the potential to cause hyperpigmentation, but minocycline is the member of this antibiotic family most commonly associated with this side effect. ${ }^{1}$ Up to $20 \%$

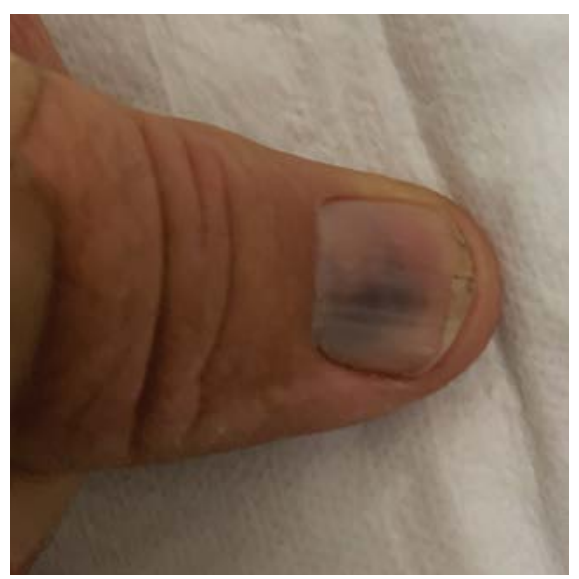

Figure 2. The patient's thumbnail 
of long-term (more than four years) users of minocycline will developed some form of medication-induced hyperpigmentation.

\section{ANSWER 4}

Minocycline-induced pigmentation can occur in many different body areas, including: ${ }^{3}$

- cutaneous (skin, nails)

- oral cavity (teeth, mucus membranes, alveolar bone and hard palate)

- ocular (sclera, conjunctiva)

- skeleton and cartilage (vertebra, costal cartilage, parietal bone)

- viscera and body fluids (thyroid, aortic and mitral valves, athereosclerotic plaques, breast milk).

\section{ANSWER 5}

There are three types of minocyclineinduced hyperpigmentation. ${ }^{3}$ These are summarised in Table 2.

\section{ANSWER 6}

Type I hyperpigmentation is not affected by the dose and duration of minocycline use; however, types II and III are associated with a lifetime dose of $>70-100 \mathrm{~g}$.

\section{ANSWER 7}

Specific forms of nail changes have been associated with the following medications: ${ }^{1,4}$

- zidovudine, PUVA (psoralens), hydroxyurea and chemotherapeutic medications can cause brown or black transverse or longitudinal bands

- antimalarials such as hydroxychloroquine and chloroquine can cause a brownish colour change to the nail bed

- tetracyclines, including minocycline, can also cause a yellow transverse discolouring.

Other medications with the potential to cause skin hyperpigmentation include: ${ }^{4}$

- an extensive array of antineoplastic agents

- immunosuppressants including etanercept and cyclosporin

- hyaluronic acid

- psychotropics including phenothiazines (eg prochlorperazine, chlorpromazine) and olanzapine

- antidepressants including imipramine, amitriptyline, citalopram, sertraline and mirtazapine

\section{Table 1. The patient's current medications}

\begin{tabular}{lll}
\hline Condition & Medication and dose & Duration \\
\hline Systemic osteoarthritis & $\begin{array}{l}\text { Paracetamol } 665 \mathrm{mg} \text {, two tablets } \\
\text { three times per day }\end{array}$ & Three years \\
\hline Major depression & $\begin{array}{l}\text { Venlafaxine sustained release } \\
150 \mathrm{mg} \text { once daily }\end{array}$ & Five years \\
\hline Hypertension & Telmisartan $40 \mathrm{mg}$ once daily & Five years \\
\hline Dyslipidaemia & Rosuvastatin $20 \mathrm{mg}$ once daily & Five years \\
\hline Rosacea & Minocycline $50 \mathrm{mg}$ once daily & $\begin{array}{l}\text { Intermittently but } \\
\text { recurrently for } 10 \text { years }\end{array}$
\end{tabular}

Table 2. Types of minocycline-induced pigmentation

\begin{tabular}{lll}
\hline Type & Pattern of involvement & Histopathology \\
\hline Type I & $\begin{array}{l}\text { Blue-black macules in areas of existing } \\
\text { scarring (eg past acne scars) }\end{array}$ & $\begin{array}{l}\text { Minocycline degradation products } \\
\text { bound to haemosiderin, ferritin } \\
\text { or iron }\end{array}$ \\
\hline Type II & $\begin{array}{l}\text { Blue-black, brown or slate-grey discoloration } \\
\text { of healthy skin; most notably affects anterior } \\
\text { lower leg and ankle and arms }\end{array}$ & $\begin{array}{l}\text { Insoluble complexes of } \\
\text { minocycline bound to iron }\end{array}$ \\
\hline Type III & $\begin{array}{l}\text { Muddy-brown hue of a generalised and } \\
\text { symmetrical distribution on healthy, } \\
\text { sun-exposed skin }\end{array}$ & $\begin{array}{l}\text { Melanisation of the basal cell; } \\
\text { minocycline may be found without } \\
\text { chelation to iron }\end{array}$ \\
\hline
\end{tabular}

\section{Key points}

- Medication-induced colouration change of the skin and nails is a well-recognised potential side effect of all tetracycline antibiotics (excluding doxycycline), particularly minocycline.

- The risk of developing medicationinduced colouration change from minocycline increases with increased dose and duration of use.

- Should colouration change develop, the patient can be reassured the change is benign, but it is advisable to cease the offending agent.

\section{Author}

Christopher Dalby DCH (USyd), BPharm, MBBS (UQ), FRACGP, Associate Lecturer, The University of Queensland, Qld; General Practitioner, Crestmead Medical Centre, Qld

Competing interests: None.

Funding: None.

Provenance and peer review: Not commissioned, externally peer reviewed.

Correspondence to:

drchrisdalby@gmail.com 


\section{References}

1. Brian W. Drug-induced nail disease. Hamilton, NZ: Dermnet NZ, 2017. Available at https://dermnetnz. org/topics/drug-induced-nail-disease [Accessed 6 December 2020].

2. Park SW, Shin HT, Lee KT, Lee DY. Medical concern for colloidal silver supplementation: Argyria of the nail and face. Ann Dermatol 2013;25(1):111-12. doi: 10.5021/ad.2013.25.1.111.

3. Eisen D, Hakim MD. Minocycline-induced pigmentation. Incidence, prevention and management. Drug Saf 1998;18(6):431-40. doi: 10.2165/00002018-199818060-00004.

4. Krause W. Drug-induced hyperpigmentation: A systematic review. J Dtsch Dermatol Ges 2013;11(7):644-51. doi: 10.1111/ddg.12042.

5. Therapeutic Guidelines. eTG complete. West Melbourne, Vic: Therapeutic Guidelines Limited, 2002. 